\title{
OPTIMIZATION OF HUMAN SOMATIC CELLS CRYOPRESERVATION PROTOCOLS BY POLYETHYLENE GLYCOLS
}

Using of polyethylene glycol in optimization of human somatic cells of cryopreservation protocols was analyzed. Low molecular weight PEG as vitrification solution supplement exhibited a high cooling speed and provided cell survival in $200 \%$ comparing with control. It allows recommending the use of low molecular weight PEG in vitrification environment for effective cell vitrification protocols.

KEY WORDS: cryopreservation, vitrification, polyethylene glycol, cooling rate, cell survival, freezing protocols.

INTRODUCTION. Vitrification is the solidification of a liquid brought about not by crystallization but by an extreme elevation in viscosity during cooling [1]. It is a widely applied alternative to standard slow programmable freezing methods for cryopreservation because of the higher survival rates of cells after thawing [2, 3]. Vitrification was first proposed in 1985 by Greg Fahy and William F. Rall [4] as a method for cryopreserving complex tissues such as whole organs. The motivation for vitrification was that conventional freeze preservation invariably destroyed organs by disrupting sensitive tissue structures with ice crystals [5]. Adding a high concentration of cryoprotectants can limit the amount of ice that forms during freezing so that less destroying the normal structure of the tissue occurs. But freezing with high cryoprotectant concentrations still causes serious structural damage. Combination of structural damage and toxicity makes recovery of frozen neural tissue impossible with current technology [5].

Vitrification of water requires an ultra-rapid cooling (e.g. 10 million degrees per second for pure water), but can be achieved without cryoprotectants. Only in 2005 the cooling rate required to form a glassy state in pure water was achieved [6]. The necessary cooling rates for solutions were significantly less than for pure liquids. For aqueous solutions of typical cryoprotectants, cooling rates of

(C) O. M. Perepelytsina, A. P. Uhnivenko, D. P. Burlaka, S. V. Bezuhlyi, M. V. Sydorenko, 2016. about $0.1-10^{\circ} \mathrm{C} / \mathrm{sec}$ (roughly $10-1,000^{\circ} \mathrm{C} / \mathrm{min}$ ) are sufficient to achieve vitrification [7].

Cryoprotectants, or cryoprotective agents (CPAs) have been extensively used for vitrification $[16,17]$. CPAs are chemicals which prevent cell damage caused by cryopreservation [8]. Such substances as alcohols, amides, oxides and polymers with corresponding functional groups can be effective CPAs. These chemicals increase the viscosity of aqueous solutions, reduce the freezing point and lower the ice nucleation temperatures of aqueous solutions. Some CPAs can reduce the glass transition temperature of a solution. CPAs from the point of view of ability to cell penetration can be good penetrating (dimethyl sulfoxide, glycerol, propylene glycol, ethylene glycol, methanol), non-penetrating (mono-, di- and polysaccharides; such polymers as polyethylene glycol, polyvinyl pyrrolidone and polyvinyl alcohol) and mixed-action CPAs (polyethylene oxide). For polymeric CPAs there are restrictions on molecular mass due to data about its cryoprotective properties, rheology and toxicity: 100-1500 Da for polyethylene oxide, 12.5-25 kDa for polyvinyl pyrrolidone and 250-500 kDa for hydroxyethyl starch [9].

So, effective CPAs must be low- or non-toxic, well-soluble in water and aqueous solutions. It has to lower the ice nucleation and completely suspend ice crystallization from CPA-water eutectic system. At the same time it should not precipitate salts and proteins from aqueous solutions before transition 
into amorphous state. Unfortunately, some substances (for example, methanol and ethanol) with good physicochemical properties can not be used as CPAs due to high toxicity even in low concentrations.

Main properties of CPAs caused by the presence in their molecules groups that can form hydrogen bounds. Substances that can form a network of hydrogen bonds, such as polyhydric alcohols, significantly increase the viscosity of aqueous solutions, which allow reducing the required concentration of CPA. With the further water freezing CPA solutions became hypertonic, that leads to partial dehydration of cell. In this state intracellular liquid cell media going super cooled and suppress the ice formation.

Usually cryopreservation solutions (mixtures of CPA with some additions) are less toxic than pure CPA. In most cases cryopreservation solutions includes penetrating CPA, non-penetrating CPA (optional ingredient), carrier solution and ice blocker (optional ingredient) [17].

One of the main requirements for penetrating CPA is the ability to rapidly go through the cell membrane and easily removed from it. It reduces osmotic effects of cooling and further warming. Fast penetration of cell by CPA prevents the formation of damaging concentration gradients between extraand intracellular environment on cell membrane in selected temperature range. Main disadvantage of penetrating CPA is necessity of removing CPA from cells after thawing. In another case the heavy damage of cell membranes and intercellular structures can be derived. CPA ability to penetrate cells depends on molecular mass, temperature, type of cells and properties of cell membranes.

Protective effect of non-penetrating CPA caused by the ability to partially dehydration of cells, that reduces the probability of intracellular ice crystallization. Non-penetrating CPA are usually less toxic than penetrating CPA at the same concentration.

Carrier solution contains salts, osmotic agents, $\mathrm{pH}$ buffers, and sometimes nutritive ingredients or apoptosis inhibitors. The ingredients are usually present at near isotonic concentration (300 milliosmoles) so that cells neither shrink nor swell when held in carrier solution [10].

Ice blockers are synthetic ice interface dopants specifically designed to bind to the basal plane and prism faces of ice crystals (and ice nucleates) [11]. Molecules of ice blockers must have the spacing polar groups at intervals corresponding to the lattice spacing of water molecules on the crystal faces of ice. Low molecular weight polyvinyl alcohol and polyglycerol, called X-1000 and Z-1000, and biological antifreeze proteins are examples of ice blockers [11, 12].

The aim of this study was to find the optimal ratio of penetrating (DMSO) and non-penetrating (saccharose and polyethylene glycols) cryoprotectants to achieve the greatest survival of human somatic cells in the two-step process of vitrification.

METHODS OF RESEARCH. Breast adenocarcinoma cell line MCF-7 was kindly presented by of Bank of cell lines of man and animals R. Ye. Kavetskyi Institute of Experimental Pathology, Oncology and Radiobiology NAS Ukraine. Cells were incubated under standard conditions in $5 \%$ of $\mathrm{CO}_{2}$, $95 \%$ humidity in RPMI - 1640 medium (Sigma) which was supplemented with $10 \%$ fetal bovine serum (FBS, Sigma, USA) and $40 \mathrm{mg} / \mathrm{ml}$ gentamycin (Sigma) for cell culture. Also buffered solution of 1 M HEPES (Sigma) pH 7.4 was used. For washing cells phosphate - saline buffered solution (PBS): $1.5 \mathrm{mM} \mathrm{KH}_{2} \mathrm{PO}_{4}, 8.1 \mathrm{mM} \mathrm{Na}_{2} \mathrm{HPO}_{4}, 2.7 \mathrm{mM} \mathrm{KCl}$, $140 \mathrm{mM} \mathrm{NaCl}$ was used.

Vitrification solutions (VS) on the first stage of investigation were based on saline $(0.9 \% \mathrm{NaCl})$ with supplements according to Table 1 . VS were used for determination of cooling rate by timedependent thermometry. Glucose (Mr=180.16 Da), saccharose $(\mathrm{Mr}=342.30 \mathrm{Da})$, glycerol $(\mathrm{Mr}=78.13 \mathrm{Da})$ and dimethyl sulfoxide ( $\mathrm{Mr}=92.09 \mathrm{Da}$ ) were used as cryoprotective agents (Table 1) for estimation of cooling rate at the first stage of our investigation.

Table 1 - Cryopreservation solutions studied on the cooling rate stage

\begin{tabular}{|l|c|c|c|c|}
\hline Name & Glucose, M & Saccharose, M & Glycerol, \% & DMSO, \% \\
\hline VS1.1 & 0.2 & - & - & - \\
\hline VS1.2 & - & 0.2 & - & - \\
\hline VS1.3 & - & - & 5 & - \\
\hline VS1.4 & - & - & 2.5 & 5 \\
\hline VS1.5 & - & - & - & 2.5 \\
\hline VS1.6 & - & - & 5 & - \\
\hline VS1.7 & - & 0.2 & 2.5 & 2.5 \\
\hline VS1.8 & -2 & - & 2.5 & - \\
\hline VS1.9 & 0.2 & - & 5 & 2.5 \\
\hline VS1.10 & \multicolumn{5}{l}{} \\
\hline
\end{tabular}


For detection of cell viability after vitrification RPMI (Sigma, USA) medium with $10 \%$ of FBS (Sigma, USA) we used. End concentrations and supplements are demonstrated in Table 2.

Determination of cooling rate by timedependent thermometry.

Boiling liquid nitrogen was cooled to $-210^{\circ} \mathrm{C}$ by pumping out air and reducing pressure in the Dewar flask. Then the air carefully returned to the Dewar flask and then test-tube with sample (Table 1) and thermo-sensor immersed in liquid nitrogen. Changes of temperature were recorded during 118 seconds, after that test-tube was removed from liquid nitrogen and prepared for the next sample.

Cell culture studies. Monolayer culture (2-D culture). Study design.

MCF-7 cells in 2-D culture was cultured five days in full culture medium. For freezing several groups were formed with different condition of vitrification solutions (Table 2). After thawing cell viability was investigated by MTT-assay, light microscopy and tripan blue staining. Micro-photos of $2-D$ cell cultures were made after 7 days of incubation. assay.

Analysis of cell viability by MTT - colorimetric

MTT test was used in order to analyze the impact of vitrification conditions on cell viability. The MTT-test was based on conversion of tetrazolium salts to farmasan crystals by $\mathrm{NAD}(\mathrm{P}) \mathrm{H}$-dependent mitochondrial oxidoreductase enzymes in alive cells. Protocol was described by T. Mosmann [18]. In brief, MCF-7 cells after thawing were incubated in full culture medium during 24 hours. Then it was analyzed with 3-[4,5-dimethylthiazol-2]-2,5diphenyltetratetrazolium (MTT) colorimetric assay. $1 \cdot 10^{4}$ MCF-7 cells were seeded in a 96-well plate. To $100 \mu$ l of cells suspension $20 \mu$ of MTT solution ( $5 \mathrm{mg} / \mathrm{ml}$ PBS, Sigma) was added. After that cells were incubated with MTT during $4 \mathrm{~h}$ in standard conditions. Mitochondrial dehydrogenases of viable cells cleave the tetrazolium ring, yielding purple MTT formazan crystals which are insoluble in

Table 2 - Cryopreservation solutions studied aqueous solutions. The resulting purple solution is spectrophotometrically measured. An increase in cell number results in an increase in the amount of MTT formazan formed and an increase in absorbance. Then samples were centrifuged under $1500 \mathrm{~g}$ during $5 \mathrm{~min}$ and supernatant was extracted. In all wells were added $10 \mu \mathrm{l}$ DMSO (Sigma) for MTT crystals dilution and $20 \mu \mathrm{l}$ of $25 \mathrm{mM}$ glycine. Optical absorption was detected on multi-well spectroscopy reader Multiscan (Labsystem, Finland) (OP540 nm).

\section{Statistical analysis.}

In common case of the biochemical studies a random variable is obviously normal or close to normal distribution, but a set of samples has a small amount that is not sufficiently representative. As with the basic parameters can not be estimated reliably, there is a need for statistical evaluation of selective parameters. Section of mathematical statistics, which is dedicated to the processing of small samples $(2 \leq n<20)$, is known as microstatistics. Underlying micro-statistic estimates of normally distributed random variables is the student's distribution for small quantities. Pearson correlation coefficient was used to determine the relationship between exposure and response to experimental biological systems and deficiencies of covariance. Coefficient was calculated for the cell viability in culture and the molecular mass of polyethylene glycol by the formula [19]:

$$
\begin{gathered}
\mathbf{r}_{X Y}=\frac{\operatorname{cov}_{X Y}}{\sigma_{X} \sigma_{Y}}=\frac{\sum(X-\bar{X})(Y-\bar{Y})}{\sqrt{\sum(X-\bar{X})^{2} \sum(Y-\bar{Y})^{2}}} \\
\bar{X}=\frac{1}{n} \sum_{t=1}^{n} X_{t} \bar{Y}=\frac{1}{n} \sum_{t=1}^{n} Y_{t} \text { _average of }
\end{gathered}
$$

the samples

The correlation coefficient ranges from minus one to plus one. Thus for independent parameters it is 0 , and for closely related approaches to the module of one. For statistical analysis processing of results and evaluation carried out by student's test. Reported $p$ values was ${ }^{*} p \leq 0.05$ or ${ }^{* *} p \leq 0.01$.

on the cell viability stage (end concentration)

\begin{tabular}{||c|c|c|c|c|}
\hline Name & FBS, $\%$ & Saccharose, M & PEG(MM), \% & DMSO, \% \\
\hline VS2.1 & 10 & - & - & 10 \\
\hline VS2.2 & 20 & - & - & 10 \\
\hline VS2.3 & 10 & 0.2 & $(1500) 10$ & 5 \\
\hline VS2.4 & 10 & - & $(4000) 10$ & 5 \\
\hline VS2.5 & 10 & - & $(1500) 10$ & 5 \\
\hline VS2.6 & 10 & 0.2 & $(4000) 10$ & 5 \\
\hline VS2.7 & 10 & 0.2 & $(15000) 10$ & 5 \\
\hline VS2.8 & 10 & 0.2 & $(20000) 10$ & 5 \\
\hline VS2.9 & 10 & 0.2 & $(40000) 10$ & 5 \\
\hline VS2.10 & 10 & 0.2 & & \\
\hline
\end{tabular}


RESULTS AND DISCUSSION.

\section{Cooling rate dependencies.}

Cooling rate was determined by the area where the temperature graph was similar to linear: approximately between $-10^{\circ} \mathrm{C}$ and $-190^{\circ} \mathrm{C}$.

As shown in Table 3 , cooling rate of pure $0.2 \mathrm{M}$ glucose solution (VS 1.1, Fig.1 $\mathrm{f}$ ) was bigger than pure $0.2 \mathrm{M}$ saccharose solution (VS 1.2, Fig.1 g) and other pure and mixed studied solutions (VS 1.3-1.10, Fig. $1 \mathrm{~h}-0$ ). Obviously, reducing the concentration of CPA leaded to decrease of cooling rate. $5 \%$ solutions of glycerol (VS 1.3) and DMSO (VS 1.5) demonstrated similar results, but $2.5 \%$ glycerol showed better result, than the $2.5 \%$ DMSO (VS 1.6). In mixed solutions samples with $5 \%$ glycerol (VS 1.7, 1.10) were indicated better results, than for samples with $2.5 \%$ glycerol and $2.5 \%$ DMSO (VS 1.8, 1.9). Also, the mixed solutions with glucose (VS 1.9, 1.10) showed slightly better results, than the samples with saccharose (VS 1.7, 1.8), but the difference was negligible (Fig. 1).

No correlation between cooling rate and such parameters, as molar mass, molar concentration and concentration of polar groups, was observed at this stage of investigation. But correlation between molecular mass and cooling rate in the line of PEG was exist (Table 4). For the determination of the mechanism of dependency between cooling rate and composition of complex cryoprotectant solutions further researches are required.

Table 3 - Cooling speed in cryopreservation solutions

\begin{tabular}{|l|c|c|c|c|c|c|c|c|c|c|}
\hline Name & VS 1.1 & VS 1.2 & VS 1.3 & VS 1.4 & VS 1.5 & VS 1.6 & VS 1.7 & VS 1.8 & VS 1.9 & VS 1.10 \\
\hline $\begin{array}{l}\text { Cooling rate, } \\
{ }^{\circ} \text { C/min }\end{array}$ & 322.0 & 261.3 & 279.6 & 274.3 & 281.3 & 192.0 & 276.7 & 235.3 & 257.0 & 279.6 \\
\hline
\end{tabular}

Table 4 - Cooling speed in cryopreservation solutions with PEG

\begin{tabular}{|c|c|c|c|}
\hline \multirow{2}{*}{ Thermo couple in: } & \multirow{2}{*}{$\mathrm{MM}, \mathrm{Da}$} & \multicolumn{2}{|c|}{ Cooling rate, ${ }^{\circ} \mathrm{C} / \mathrm{min}$} \\
\cline { 3 - 4 } & & From $-4{ }^{\circ} \mathrm{C}$ to $-40{ }^{\circ} \mathrm{C}$ & From $-40{ }^{\circ} \mathrm{C}$ to $-200{ }^{\circ} \mathrm{C}$ \\
\hline LN & - & 14118 & 19500 \\
\hline VS 2.6 & $\sim 1500$ & 140.1 & 278.8 \\
\hline VS 2.7 & $\sim 4000$ & 145.3 & 263.5 \\
\hline VS 2.8 & $\sim 15000$ & 150.2 & 258.1 \\
\hline VS 2.9 & $\sim 20000$ & 177.6 & 255.6 \\
\hline VS 2.10 & $\sim 40000$ & 180.3 & 131.4 \\
\hline Pearson' correlation & & 0.89 & -0.92 \\
\hline
\end{tabular}

Cell viability after cycle of freezing/thawing.

The survival percentage of the human somatic cells was determined by MTT test after 3 days of cultivation. In Table 5 and Fig. 2 was demonstrated how the composition of the vitrification medium affects on cell viability after freezing/ thawing cycle.

According to obtained data the smallest cell survival after a cycle of freezing/thawing obviously observed in 10-20\% serum and $10 \%$ DMSO (VS2.1, VS 2.2, Table 2, Table 5, Fig. 2).

Adding $200 \mathrm{mM}$ of Saccharose (VS 2.3) to medium significantly increased the percentage of alive cells. Since VS 2.3 was used in the laboratory as a carrier solution, effectiveness of another solutions was compared only with VS 2.3 (Fig. 2). After following measurements of cell survival rate it was observed that the presence of $10 \%$ of low molecular weight PEG (1.5 kDa and $4 \mathrm{kDa})$ in vit- rification solutions lead to substantially increase the percentage of alive cells in culture after freezing/ thawing cycle. For PEG $1.5 \mathrm{kDa}$ cell viability was $132 \%$ without saccharose and $196 \%$ with saccharose in comparison with control. For PEG $4 \mathrm{kDa}$ without saccharose $107.9 \%$ viability was not statistically significant, but with saccharose it was more that $200 \%$ of cell viability. Further increase of PEG molecular weight $(15-40 \mathrm{kDa})$ was ineffective to the preservation of cell mass (Table 5, Fig. 2).

Our data also confirmed the results of cell cultures staining on 7-th day of cultivation after freezing/thawing cycle in the presence of various concentrations of cryoprotectants (Fig. 3).

So, we can conclude that the presence of high molecular compounds in vitrification solutions leads to smooth the curve of temperature decrease and to slower temperature decrease, compared to the

Table 5 - Viability of MCF-7 in different vitrification solutions

\begin{tabular}{|l|c|c|c|c|c|c|c|c|c|c|}
\hline & VS 2.1 & VS 2.2 & VS 2.3 & VS 2.4 & VS 2.5 & VS 2.6 & VS 2.7 & VS 2.8 & VS 2.9 & VS 2.10 \\
\hline $\begin{array}{l}\text { Optical density, } \\
540 \mathrm{~nm}\end{array}$ & 0.256 & 0.402 & 0.457 & 0.603 & 0.494 & 0.897 & 0.969 & 0.744 & 0.892 & 0.440 \\
\hline Cell viability, \% & 56.01 & 88.0 & 100.0 & 132.0 & 107.9 & 196.2 & 212.0 & 162.7 & 195.2 & 96.2 \\
\hline
\end{tabular}




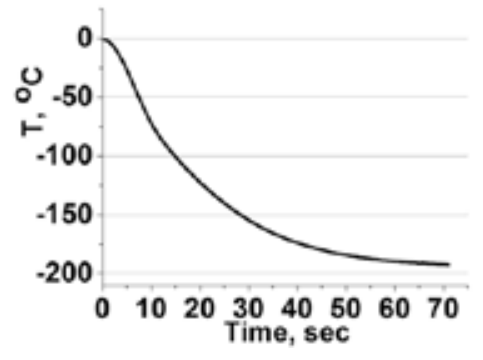

a
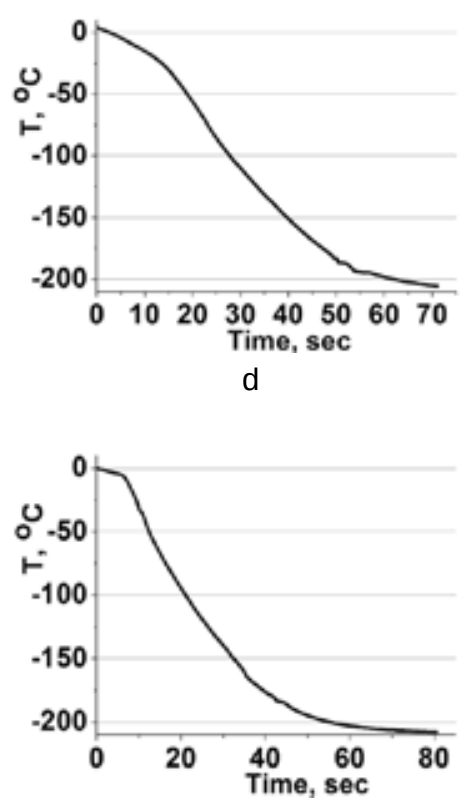

g
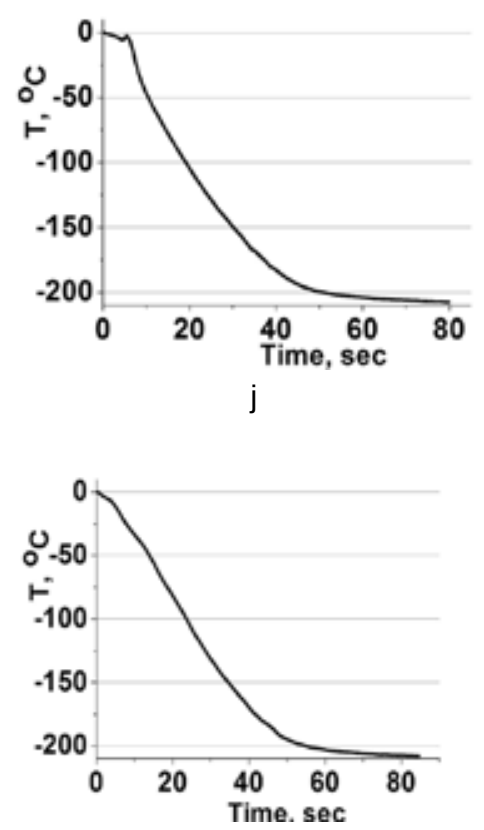

$\mathrm{m}$

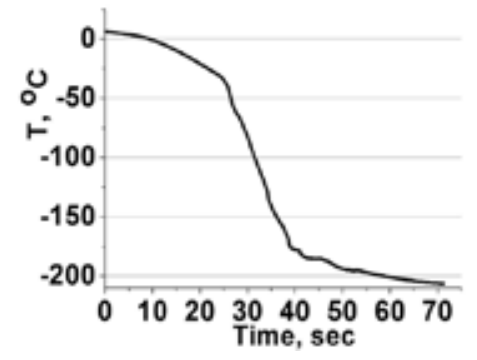

b

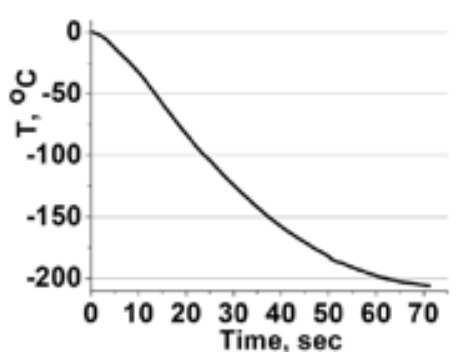

e

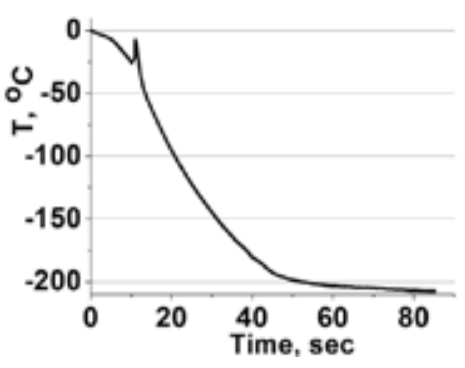

h
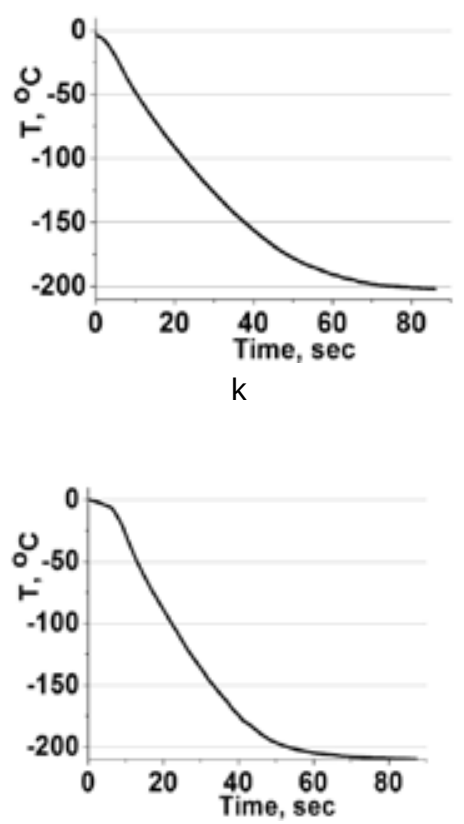

$\mathrm{n}$
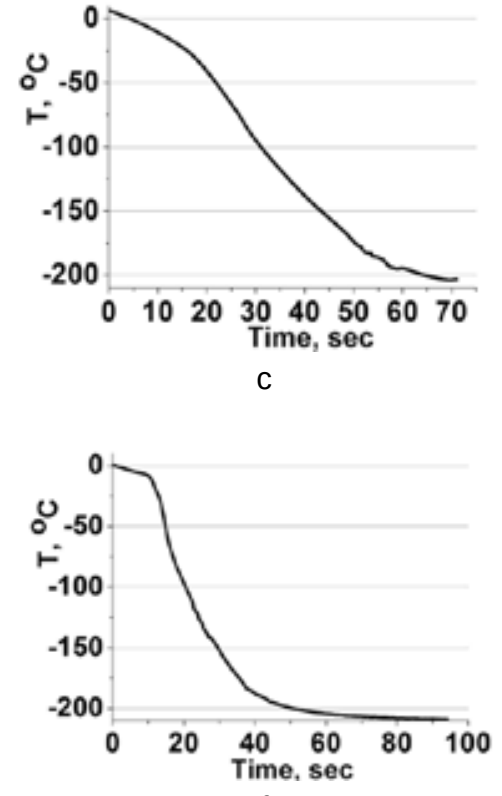

f

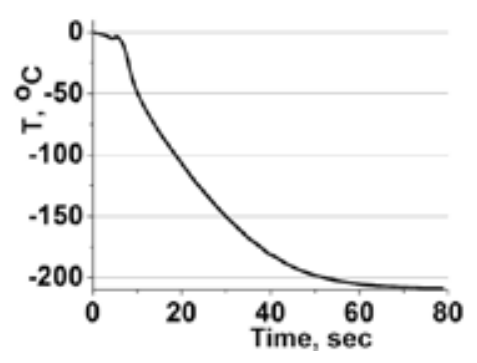

i
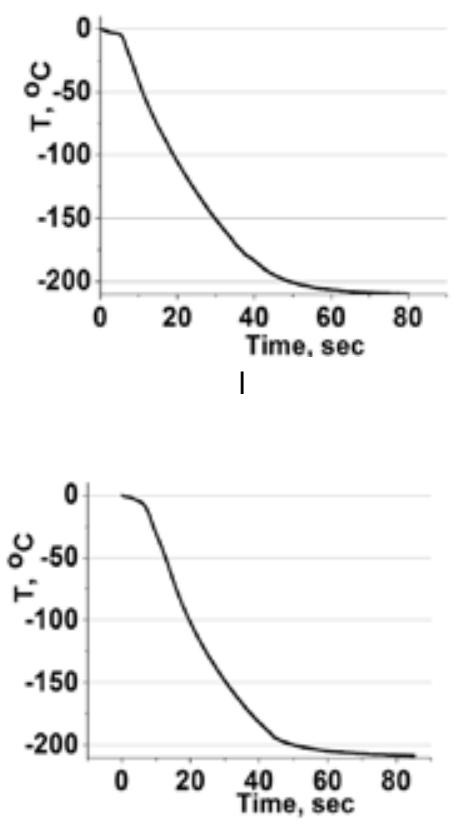

0

Fig. 1. Cooling rate of CPA solutions: a - FBS+DMEM; b - Saccharose 0.2 M; c - PEG 15; d - PEG 20; e - PEG 40; f - VS1.1; g - VS1.2; h - VS1.3; i -VS1.4; j - VS1.5; k - VS1.6; I - VS1.7; m - VS1.8; n - VS1.9; o - VS1.10. 


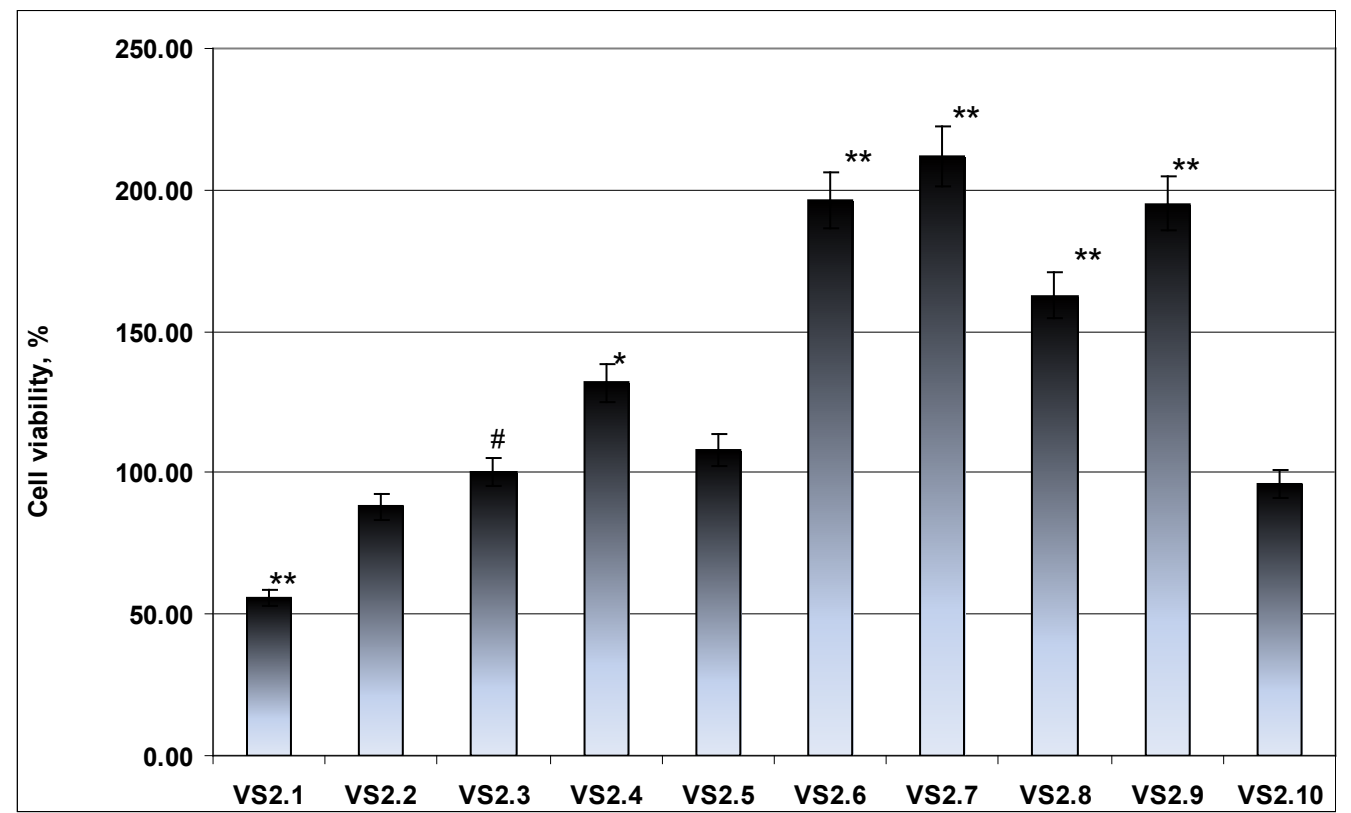

Fig. 2. The viability of the cell culture after freezing/thawing cycle in the presence of various concentrations of cryoprotectants; ${ }^{*}-p \leq 0.05 ;{ }^{* *}-p \leq 0.01,{ }^{*}-$ control.

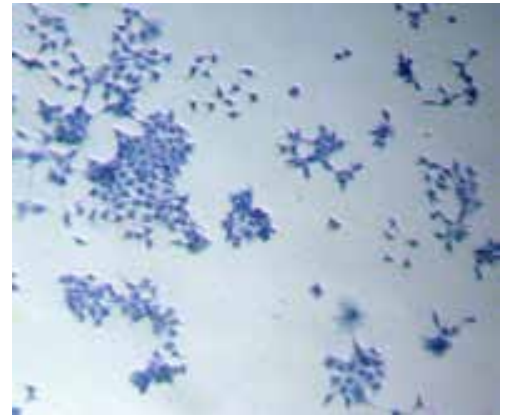

a

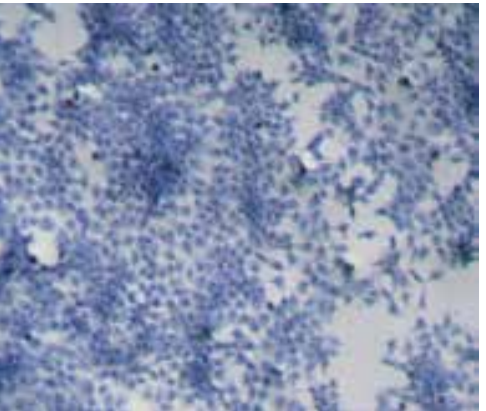

d

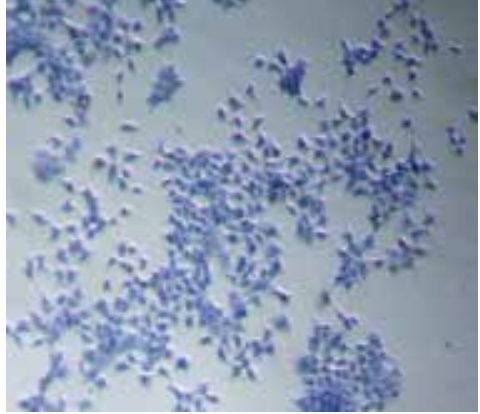

b

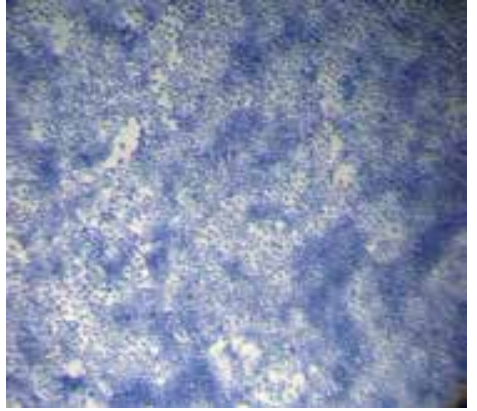

e

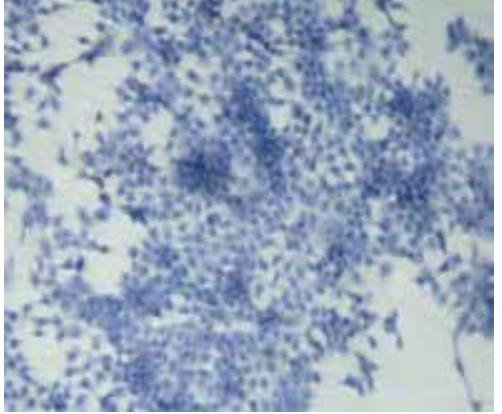

C

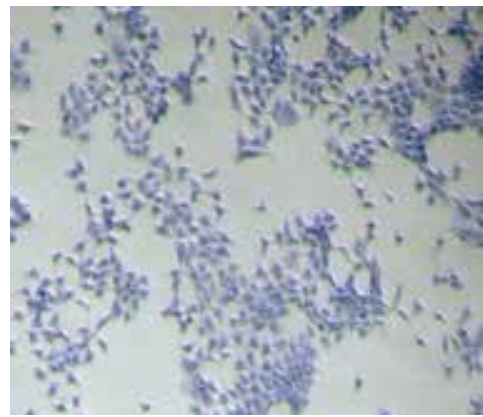

$\mathrm{f}$

Fig. 3. Cell cultures on 7-th day of cultivation after freezing/thawing cycle: $a-V S 2.1 ; b-V S ~ 2.2 ; c-V S ~ 2.3 ; d-V S ~ 2.4 ;$ e - VS 2.6; f - VS 9.9.

saccharose solution. It slows the freezing speed and probably reduced cell survival rate. At the same time low molecular PEG (1.5 kDa) was more effective cryoprotectant, than high molecular PEG and saccharose. Adding of low molecular PEG to the vitrification solution increased the cell viability in 1.3 times (1.96-2.12 times with saccharose). Simultaneously, the presence of saccharose provided more effectively freezing conditions, that can be explained by several mechanisms. Firstly, presence of saccharose leads to osmotic dehydration of cells and reduction of intracellular ice formation. Secondly, saccharose provides the energy source to the cells for quick recovery after thawing that leads to increase of living cells percentage. Presence of PEG $1.5 \mathrm{kDa}$, according to the literature data, leads to increase of osmotic concentration of all components of the intracellular environment, suspending of biochemical processes in the cell, chromatin condensation [20] and modifying of the 
structural properties of cell membranes [21]. In addition, low molecular PEG are actively involved in molecular mechanisms of recovery of plasma membranes of cells and preventing damage to mitochondria [22]. Saccharose and PEG are recognized as food applications, what in used concentrations are not harmful, but rather have a proven positive effect on human cells. Using of these compound allow to create a favorable conditions for minimal cell damage during freezing and unfreezing quick recovery with minimal side effects in human cells.

CONCLUSIONS. Physical and biological parameters of vitrification of human somatic cells were analyzed. The possibility of increasing cells survival by adding polyethylene glycol of different molecular weights was shown. It was found that the low molecular weight PEG (1.5 kDa) exhibited a sufficiently high cooling rate $\left(-140{ }^{\circ} \mathrm{C} / \mathrm{min}\right)$ in the temperature range from $-4^{\circ} \mathrm{C}$ to $-40^{\circ} \mathrm{C}$, and a high cooling speed $\left(-278^{\circ} \mathrm{C} / \mathrm{min}\right)$ in the range $-40^{\circ} \mathrm{C}$ to $-200^{\circ} \mathrm{C}$. Simultaneously, PEG $(1.5 \mathrm{kDa})$ allowed to achieve the highest cell survival up to $200 \%$ in comparison with control samples. Thus, the physicochemical and molecular biological properties of low molecular weight PEG suggests the possibility of its application in vitrification environment for effective freezing protocols.

\section{REFERENCES}

1. Fahy, G. M., MacFarlane, D. R., Angell, C. A., Meryman, H. T. (1984). Vitrification as an approach to cryopreservation. Cryobiology. - 21. - P. 407-426.

2. Takahashi, K., Tanabe, K., Ohnuki, M., Narita, M., Ichisaka, T., Tomoda, K., Yamanaka, S. (2007). Induction of pluripotent stem cells from adult human fibroblasts by defined factors. Cell, 131 (5), 861-872.

3. Nakagawa, M., Koyanagi, M., Tanabe, K., Takahashi, K., Ichisaka, T., Aoi, T., Okita, K., Mochiduki, Y., Takizawa, N., Yamanaka, S. (2008). Generation of induced pluripotent stem cells without Myc from mouse and human fibroblasts. Nat Biotechnol, 26 (1), 101-106.

4. Rall, W. F., Fahy, G. M. (1985). Ice-free cryopreservation of mouse embryos at -196 degrees $C$ by vitrification. Nature, 313 (6003), 573-575.

5. Chamberlain, F. (2000). Vitrification Arrives! New Technology Preserves Patients without Ice Damage. Cryonics, 21 (4), 4-9.

6. Bhat, S. N., Sharma, A., Bhat, S. V. (2005). Vitrification and glass transition of water: insights from spin probe ESR. Phys Rev Lett, 95 (23), 695-702.

7. Wolfe, J., Bryant, G. (2001). Cellular cryobiology: thermodynamic and mechanical effects. International Journal of Refrigeration, 24 (5), 438-450.

8. Collins English Dictionary - Complete and Unabridged, 12th Edition 2014.

9. Belous, A. M., Gryshchenko, V. I. (1994). Cryobiology. Kyiv, Naukova Dumka, 431. (in russian)

10. Wowk, B. (2007). How cryoprotectants work. Cryonics, 28 (3), 3-7.

11. Wowk, B., Leitl, E., Rasch, C.M., Mesbah-Karimi, N., Harris, S.B., Fahy, G.M. (2000). Vitrification enhancement by synthetic ice blocking agents, Cryobiology, 40, 228-236.

12. Wowk, B., Fahy, G.M. (2002). Inhibition of bacterial ice nucleation by polyglycerol polymers. Cryobiology, 44, 14-23.
13. Bakaltcheva, I.B., Odeyale, C.O., Spargo, B.J. (1996). Effects of alkanols, alkanediols and glycerol on red blood cell shape and hemolysis. Biochem Biophys Acta, 1280, 73-80.

14. Fahy, G.M., Wowk, B., Wu, J., Paynter, S. (2004). Improved vitrification solutions based on the predictability of vitrification solution toxicity. Cryobiology, 48, 22-35.

15. Fahy, G.M., Wowk, B., Wu, J., Phan, J., Rasch, C., Chang, A., Zendejas, E. (2004). Cryopreservation of organs by vitrification: perspectives and recent advances. Cryobiology, 48, 157-178.

16. Lane, M., Bavister, B.D., Lyons, E.A., Forest, K.T. (1999). Containerless vitrification of mammalian oocytes and embryos: adapting a proven method for flash-cooling protein crystals to the cryopreservation of live cells, Nat. Biotechnol. 17, 1234-1236.

17. Stokich, B., Osgood, Q., Grimm, D., Moorthy, S., Chakraborty, N., Menze, M. (2014). Cryopreservation of hepatocyte (HepG2) cell monolayers: Impact of trehalose. Cryobiology, 69 (2), 281-290.

18. Mosmann T. (1983). Rapid colorimetric assay for cellular growth and survival: Application to proliferation and cytotoxic assayas. J Immunol Methods, 65, 55-63.

19. Rodgers, J. L., Nicewander, W. A. (1988). Thirteen ways to look at the correlation coefficient. The American Statistician, 42 (1), 59-66.

20. Parnaud, G., Corpet, D., Payrastre, L. (2001). Cytostatic effect of polyethylene glycol on human colonic adenocarcinoma cells, Int. J. Cancer, 92, 63-69.

21. Shi, R. (2013). Polyethylene glycol repairs membrane damage and enhances functional recovery: a tissue engineering approach to spinal cord injury, Neurosci. Bull., 29, 460-466.

22. Nehrt, A., Hamann, K., Ouyang, H., Shi, R. (2010). Polyethylene glycol enhances axolemmal resealing following transection in cultured cells and in ex vivo spinal cord. Journal of neurotrauma, 27, 151-161. 


\section{ОПТИМІЗАЦІЯ ПРОТОКОЛІВ КРІОЗБЕРЕЖЕННЯ СОМАТИЧНИХ КЛІТИН ЛЮДИНИ ЗА ДОПОМОГОЮ ПОЛІЕТИЛЕНГЛІКОЛЮ}

\section{Резюме}

Було проаналізовано використання поліетиленгліколю при оптимізації протоколів кріозбереження соматичних клітин людини. Низькомолекулярний поліетиленгліколь як добавка до вітрифрікаційних розчинів проявив велику швидкість охолодження і продемонстрував виживаність клітин у 200 \% порівняно 3 контрольною групою. Це дозволяє рекомендувати застосування низькомолекулярного поліетиленгліколю для вітрифрікаційних середовищ для ефрективних протоколів вітрифрікації клітин.

КЛЮчОВІ СЛОВА: кріозбереження, вітрифікація, поліетиленгліколь, швидкість охолодження, виживаність клітин, протоколи заморожування.

Е. М. Перепелицина, А. П. Угнивенко, Д. П. Бурлака, С. В. Безуглый, М. В. Сидоренко ИНСТИТУТ ПРОБЛЕМ КРИОБИОЛОГИИ И КРИОМЕДИЦИНЫ НАН УКРАИНЫ, КИЕВ

\section{ОПТИМИЗАЦИЯ ПРОТОКОЛОВ КРИОСОХРАНЕНИЯ ЧЕЛОВЕЧЕСКИХ СОМАТИЧЕСКИХ КЛЕТОК С ПОМОЩЬЮ ПОЛИЭТИЛЕНГЛИКОЛЯ}

\section{Резюме}

Было проанализировано использование полиэтиленгликоля при оптимизации протоколов криосохранения человеческих соматических клеток. Низкомолекулярный полиэтиленгликоль как добавка к витрифрикационным растворам проявил высокую скорость охлаждения и продемонстрировал выживаемость клеток в 200 \% по сравнению с контрольной группой. Это позволяет рекомендовать применение низкомолекулярного полиэтиленгликоля для витрификационных сред для эфрфективных протоколов витрифрикации клеток.

КЛЮЧЕВЫЕ СЛОВА: криосохранение, витрификация, полиэтиленгликоль, скорость охлаждения, выживаемость клеток, протоколы замораживания.

Received 21.07.16

Address for correspondence: A. P. Uhnivenko, Department for Biotechnical Problems of Diagnostic Institute for problems of Cryobiology and Cryomedicine NAS Ukraine, Prospect Nauky, 42/1, Kyiv, 03028, Ukraine, e-mail: idez@ukr.net. 